\title{
Working
}

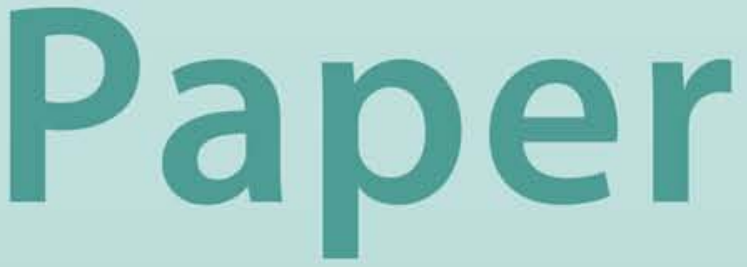




\section{Predictable Movements in Yen/DM Exchange Rates}

Qingying Kong 


\title{
IMF Working Paper
}

\author{
European I Department
}

\section{Predictable Movements in Yen/DM Exchange Rates}

Prepared by Qingying Kong ${ }^{1}$

Authorized for distribution by Carlo Cottarelli

August 2000

\begin{abstract}
The views expressed in this Working Paper are those of the author(s) and do not necessarily represent those of the IMF or IMF policy. Working Papers describe research in progress by the author(s) and are published to elicit comments and to further debate.
\end{abstract}

This paper examines the relevance of PPP, the adjustment channel of real exchange rate and the predictability of the movement in nominal exchange rate by studying the behavior of yen/DM exchange rate, using cointegration method. Results support PPP and find that the real exchange rate is mean-reverting. The change in the nominal exchange rate exhibits significant auto-regressive property. These findings imply that movements in the nominal yen/DM exchange rate is actually predictable. The error-correction model and a simple first order autoregressive model both outperform the random walk model in out-of-sample forecasting.

JEL Classification Numbers: F31; F47

Keywords: PPP, exchange rate forecast

Author's E-Mail Address: qkong@imf.org

\footnotetext{
${ }^{1}$ This paper was part of my dissertation. I am grateful for the guidance and help received from Prof. Diba, Prof. Canzoneri, and Prof. Cumby. I also benefited from Carlo Cottarelli's insightful comments. All errors remain my own.
} 
I. Introduction

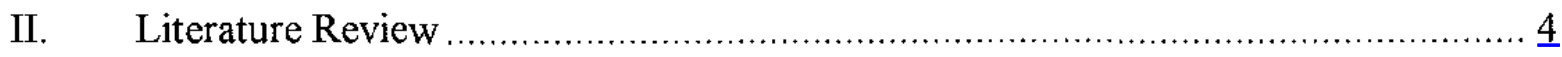

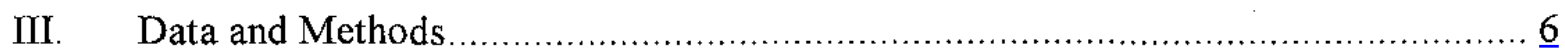

A. Purchasing Power Parity ………….................................................

Unit root tests and results.............................................................

Cointegration tests and results..................................................... $\frac{8}{2}$

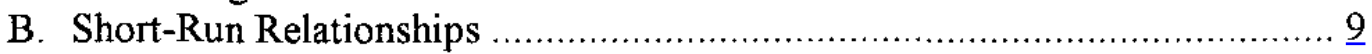

Error correction models .............................................................. 9

Autoregressive models............................................................... 10

Short-run prediction of the exchange rate...........................................11

Directional accuracy measure of forecasting .......................................12

C. Long-Run Predictability of the Nominal Exchange Rate ............................13

D. Long-Run Behavior of Real Exchange Rate .............................................

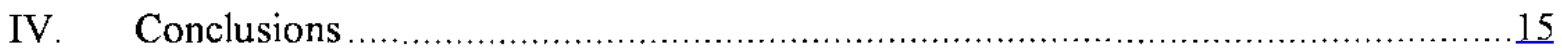

References

Figures

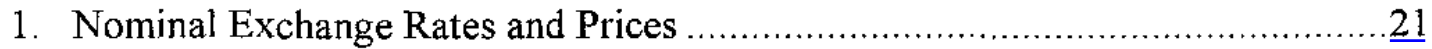

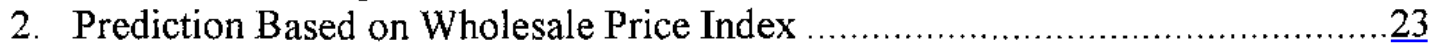

3. Prediction Based on Export Price Index ......................................................

Tables

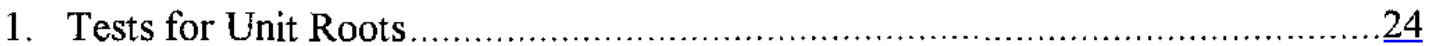

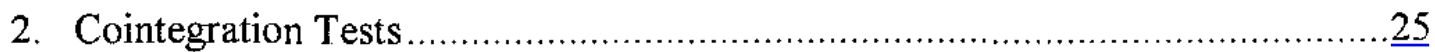

3. Short-Run Predictability Using Error Correction Model ..................................

4. Error Correction Models Selected Based on SIC …….................................29

5. Predictions of Exchange Rates (wholesale prices) …….................................

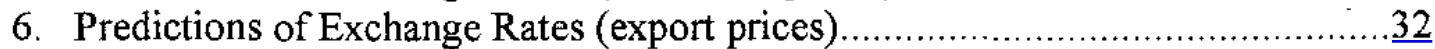

7. Rolling Forecasting Evaluation for Wholesale Price Index ..............................33

8. Rolling Forecasting Evaluation for Export Price Index ..................................34

9. Directional Accuracy Measures of Forecasting ………..............................35

10. Long-Horizon Predictability Using OLS …….......................................

11. Autoregressive Estimation for the Real Exchange Rate .................................. 


\section{INTRODUCTION}

Numerous empirical studies have examined the predictability of movements in real and nominal exchange rates. ${ }^{2}$ The stylized facts suggested by this literature are largely based on the behavior of exchange rates against the dollar. In particular, the DM and yen exchange rates against the U.S. dollar have been scrutinized extensively. By contrast, the behavior of the yen/DM cross rate has not received much attention. ${ }^{3}$ The present paper focuses on the behavior of the real and nominal yen/DM exchange rates after the advent of generalized floating in 1973.

The long-run purchasing-power-parity (PPP) hypothesis motivates existing tests for mean reversion in (the logarithm of) the real exchange rate. An extension of these tests also considers the possibility that (after logarithmic transformation) the nominal exchange rate and the ratio of the two countries' price indexes are cointegrated. These "weak-form PPP tests" do not impose the (long-run PPP) restriction of a unitary slope coefficient on the cointegrating regression. ${ }^{4}$

Froot and Rogoff's (1995b) survey of studies focusing on the behavior of individual exchange rates after 1973 does not indicate much support for long-run PPP. The weak-form PPP hypothesis fares somewhat better, but still fails to get strong support from the above studies. This lack of empirical support for the two PPP hypotheses, however, may reflect the low power of the relevant tests for unit roots and cointegration. More recent studies working with longer time series or panel data, although not unanimous in their results, find much stronger support for the two PPP hypotheses. ${ }^{5}$

If either of the two PPP hypotheses holds in the long run, then the nominal exchange rate and/or the ratio of price indexes must adjust over time, via an error-correction mechanism, to eliminate deviations from long-run equilibrium. To the extent that some of this adjustment occurs through changes in the nominal exchange rate, these changes should be predictable.

\footnotetext{
${ }^{2}$ Froot and Rogoff (1995b) survey the literature on mean reversion in real exchange rates. The literature on the near random-walk behavior of nominal exchange rates follows Meese and Rogoff (1983a).

${ }^{3}$ To our knowledge, Tronzano (1992) is the only earlier work considering the yen/DM cross rate.

${ }^{4}$ Froot and Rogoff (1995b) discuss, the possible theoretical motivations for weak-form PPP tests. One explanation for nonunitary slope coefficient is that there is a trend in the relative prices of traded and nontraded goods.

${ }^{5}$ See, for example, Canzoneri, Cumby and Diba (1996); Jorion and Sweeney (1996); and Lothian $(1990,1997)$. Two findings of the recent literature are particularly relevant for the present study. First, the panel-data tests find strong support for long-run PPP when they use the DM as reference currency (but they do not study the yen/DM rate separately). Second, Lothian (1990) finds evidence supporting long-run PPP in historical data for a number of yen exchange rates (but he does not study the yen/DM rate).
} 
The existing literature's benchmark for predicting nominal exchange-rate movements was set by Meese and Rogoff (1983a, 1983b). They showed that standard models of exchange-rate determination fail to outperform a random-walk forecast for nominal exchange rates. More elaborate attempts by Diebold and Nason (1990) and Engel and Hamilton (1990) have also failed to improve significantly on the random-walk forecast. More recent work, however, suggests some predictability in nominal-exchange-rate movements, particularly at longer horizons. ${ }^{6}$

As noted above, the present paper applies some of the existing literature's tests to the yen/DM exchange rate. To anticipate the general flavor of our results, we find support for weak-form PPP, and to a lesser extent for long-run PPP. More to the point, the error correction representations suggested by the PPP hypotheses predict up to 20 percent of the variability in the nominal yen/DM exchange rate. Moreover, the estimated error-correction models point to the presence of autocorrelation in the growth rates of the nominal exchange rate. This leads us to consider also an autoregression for the growth rate of the nominal rate as a forecasting model. Both the autoregressive model and the error-correction model outperform the geometric random-walk model with drift in out-of-sample forecasting exercises.

In what follows, section II contains a more detailed review of the relevant literature. Section III discusses the data and econometric methods used in the paper. Section IV presents the empirical results, and Section $V$ offers some concluding remarks.

\section{LITERATURE REVIEW}

Purchasing Power Parity (PPP) has been a cornerstone of the international macroeconomics literature. Under floating exchange rates, PPP becomes a theory of exchange rate determination. However, PPP is unlikely to hold continuously. Many factors (like government intervention, trading restrictions, and transportation costs) can push the actual exchange rate away from its PPP-determined level in the short run. The recent literature has focused on PPP as a guide to the long-run behavior of exchange rates.

There are several approaches to testing PPP ( see MacDonald 1989). The most common test for long-run PPP is a test of the hypothesis that the real exchange rate exhibits mean-reversion. In general, deviations from PPP seem quite large and persistent. However, advocate of PPP argue that deviations from PPP are temporary, and that over time the real exchange rate will return to its equilibrium value. According to this view, changes in the real exchange rate should be serially correlated. In contrast, the "efficient market PPP" hypothesis articulated by Roll (1979) implies the real exchange rate follows a random walk. And this view was supported by majority of the evidence, even though some studies did reject the efficient market PPP hypothesis (See MacDonald (1988), pp.217-218 for a complete review).

6 See MacDonald and Marsh (1994), MacDonald and Taylor (1993, 1994), and Mark (1995). 
A number of recent studies cast doubt even on the long-run validity of PPP (see Dornbush 1987, Frankel and Meese 1987, Meese 1990). Nonetheless, several researchers have recently utilized various techniques to reestablish support for long-run PPP. Froot and Rogoff (1995a) demonstrate that the convergence to PPP is remarkably stable across regimes with a data set spanning 700 years. Wei and Parsley (1995) confirm this convergence using panel data covering many countries in the postwar period. Parsley and Wei (1995) use a panel of 52 prices for 48 U.S. cities to estimate the rate of convergence to PPP. They found the convergence to be very fast. Cumby (1996) shows even faster convergence to PPP using an imaginative panel of Big Mac prices. Jorion and Sweeney(1996) provide evidence that the real exchange rate was mean-reverting for a panel of G-10 countries. Lothian(1997) also present evidence supporting long-term PPP. He employs various panel unit-root tests on the panel of the United States and 22 other OECD countries for the current float and found that real exchange rates can be characterized as mean-reverting.

A line of research employs another implication of PPP: the cointegrating property of nominal exchange rate and relative price. If PPP holds in the long-run, then the time series of nominal exchange rate and relative price should be cointegrated. Lothian (1990) did find that exchange-rate-adjusted price levels in Japan, the United States, the United Kingdom and France are cointegrated and real exchange rates are stationary. Canzoneri, Cumby and Diba (1996) using a panel of 13 OECD countries, find that PPP holds for a large portion of countries when the deutsche mark was used as numeraire currency.

Overall, the majority of recent studies seem to support the view that over the long haul, real exchange rates are mean-reverting. This would, in turn, imply that there exists a long run relationship between nominal exchange rates and prices of traded goods.

Work in predicting nominal exchange rates has had little success. In both papers by Meese and Rogoff (1983a, 1988), it has been shown that regression forecasts are never significantly better than the driftless random walk model for the logarithm of the nominal exchange rate. Engel and Hamilton (1990), find that their segmented-trends model is outperformed by the random walk with drift model at the four-quarter horizon for two out of the three currencies they study. And Diebold and Nason (1990) also find that the random walk forecast for log exchange rates generally performs better than their nonparametric estimates. However, Nelson Mark (1995) uses the deviation of the log exchange rate from its "fundamental value" to predict the multiple-period changes in the log exchange rate, and he concludes that "long-horizon changes in log nominal exchange rates contain an economically significant predictable component".

Ronald MacDonald has also looked at the predictability of nominal exchange rate. In MacDonald (1993) and MacDonald and Marsh (1994), they tested PPP in unrestricted form for the following U.S. dollar bilateral rates: Canadian dollar, German mark, Japanese yen, French franc, Italian lira, and U.K. pound; and three German mark bilateral rates: French franc, Italian lira, and U.K. pound. They find weak form PPP hold for these currencies. MacDonald and Marsh (1994) also show that the error correction model (ECM) can 
outperform the random walk model at longer forecasting horizon. However, the results are not overwhelmingly in support of ECM.

MacDonald and Taylor(1991, 1993, 1994) tested the monetary model of exchange rate determination and found that the unrestricted monetary model can be validated as a model characterizing the behavior of exchange rates over the long run. And, in the 1993 and 1994 articles, they also compared the out of sample forecasting ability of an ECM monetary model to the random walk model based on the root mean squared error(RMSE). The monetary ECM outperforms the random walk model at all forecasting horizons.

Ashok Parikh (1991, 1992) looked at the property of PPP using monthly data of yen and deutsche mark against the U.S. dollar, and yen-pound exchange rates from 1970 to 1990 . He found that, in general, PPP holds for most of the exchange rates in question, and there is a long-run relationship existing between the pair-wise exchange rates (cointegration is found to hold). And he also utilized the error correction model $^{7}$ to estimate the short-run relationship between the pair-wise exchange rates, and he concluded that the short-run models produced better post-sample forecasts than the random walk model does.

M. Tronzano (1992) used both conventional unit root tests and alternative varianceratio tests on three bilateral U.S. dollar denominated and the mark-denominated exchange rates, and he found the yen/DM rate performs relatively well with PPP. Using an autoregression model, he found the convergence of yen/DM rate towards long-run PPP is 10 percent per quarter.

In sum, this paper adds to the literature by using an error-correction model to predict the movement in nominal exchange rate and successfully established evidence of the predictability of nominal exchange rate.

\section{DATA AND Methons}

The data used in this paper mainly come from the International Financial Statistics(IFS) published by the International Monetary Fund (IMF) for the period from the first quarter of 1958 to the last quarter of 1996. Exchange rates are end of period figures, quoted in units of national currency per U.S. dollar. Three types of price indexes are considered in the paper: the wholesale price index; the consumer price index (which has a large nontradable component); and the export price index (which we take to be a better proxy for measuring tradable goods prices). All the series are converted to natural logarithm.

\footnotetext{
${ }^{7}$ He used the specific form of ECM suggested by Phillips and Loretan (1991), which requires the contemporaneous information on the cointegrated variables. The inclusion of a contemporaneous variable as a regressor renders this model not useful in terms of out of sample forecasting.
} 
Figure 1 presents the data series. We can see that when export prices are used to construct the PPP exchange rate, the movement in nominal exchange rate and PPP exchange rate closely follow each other. ${ }^{8}$ When wholesale prices are used, the match is not as close as that of export prices. While for consumer price indexes, the nominal exchange rate and PPP exchange rate seem to move in unrelated fashion. This suggests that the heavy component of nontraded goods in the CPI makes it a "bad" proxy for traded goods prices.

\section{A. Purchasing Power Parity}

Simple PPP states that exchange rates should tend to equalize prices for identical goods in different countries. Let $\mathrm{E}_{\mathrm{i}, \mathrm{t}}$ be the nominal exchange rate of currency i relative to currency 1 , the numeraire currency, at time $t$. If $\mathrm{E}_{\mathrm{i}, \mathrm{t}}$ is expressed in units of currency $\mathrm{i}$ per unit of the numeraire currency, purchasing power parity implies that $\mathrm{E}_{\mathrm{i}, \mathrm{t}} \mathrm{P}_{1, \mathrm{t}}{ }^{\mathrm{T}}=\mathrm{P}_{\mathrm{i}, \mathrm{t}}{ }^{\mathrm{T}}$. If we define the PPP exchange rate for country $i$ at date $t$ as

$$
R_{i, t}=\frac{P_{i, t}^{T}}{P_{1, t}^{T}}
$$

purchasing power parity implies that the nominal exchange rate $E_{i, t}$ is equal to the PPP exchange rate. A testable form is to test whether $\ln \left(\mathrm{E}_{\mathrm{i}, t}\right)$ is cointegrated with $\ln \left(\mathrm{R}_{\mathrm{i}, t}\right)$ and whether the cointegrating slope is one.

\section{Unit root tests and results}

Before we can test for cointegration among variables, we have to find out the longrun trend behavior of nominal and PPP exchange rates. We use an univariate autoregression for each series to test whether each of the series contains a deterministic trend or a stochastic trend, or possibly both. The results from the augmented Dickey Fuller (1979) test and the Phillips and Perron (1988) test are reported in Table 1.

We find strong evidence supporting the presence of unit roots in all of the data series. All the tests fail to reject the presence of unit roots in the nominal exchange rate and PPP exchange rates, with or without including a time trend in the model. And the likelihood ratio test on the coefficients of the unit root model suggests that there is no deterministic trend in the data. We therefore proceed assuming that both the nominal exchange rate and the PPP exchange rate contain a stochastic trend but no deterministic trend.

\footnotetext{
${ }^{8}$ The graphs relating nominal exchange rate and PPP exchange rate are only for the floating period. The data from the pre-Bretton Woods period were also used in the analysis for comparison. Generally, the results become weaker when the full sample is used. However, the basic conclusions remain. Throughout the paper, results are reported only for the floating period.
} 
The same analysis is carried through for the wholesale price index. The results are reported in the third column of Table 1, and the conclusions remain the same.

\section{Cointegration tests and results}

This section applies the framework developed in Søren Johansen(1991) to investigate the existence of long-run equilibrium relationships between the nominal exchange rate and domestic and foreign prices. We test the relative version of PPP theory which postulates the existence of an equilibrium balance between the levels of the nominal exchange rates and those of the domestic and foreign prices. If cointegration holds, then the above variables do not drift arbitrarily apart and PPP is verified as a long-run equilibrium condition.

Since cointegration implies that the equilibrium error in the cointegrating equation is an $\mathrm{I}(0)$ series, we also report tests that impose the cointegration relationship on the data and apply unit root tests to the equilibrium errors. These tests assume that long-run PPP holds and impose a unitary slope. The results are labeled "unitary slope" in Table 2 under the section of residual test.

When the export price indexes are used to construct the relative prices between Japan and Germany, the null hypothesis of no cointegration between this PPP exchange rate and the nominal exchange rate is rejected at the 5 percent significance level. The normalized cointegrating equation is $\ln \left(E_{i, t}\right)=-4.465+0.80 * \ln \left(R_{i, t}\right)$. However, the coefficient 0.80 is significantly different from 1 at the 5 percent significance level (with a standard error of $0.104)$. The unit root tests on the cointegrating residual show that the residual is not stationary when a unitary slope is imposed on the data. This residual test result may imply that the cointegrating slope is not unitary for the export prices. Because the power of cointegration test in small samples is low, we take the results from these two tests support the hypothesis that the nominal exchange rate and PPP exchange rate are cointegrated.

Results using the wholesale price indexes are also reported in Table 2. For wholesale prices, we can not reject the hypothesis that there is no cointegration between nominal exchange rate and PPP exchange rate at the 5 percent level, however, the likelihood ratio falls close to the 10 percent significance level. And the residual tests support the cointegrating relationship implied by $\mathrm{PPP}^{9}$. So, we consider that a cointegrating model appropriately describes the relationship between the nominal exchange rate and PPP exchange rates. The normalized cointegrating equation for whole sale prices and the nominal

\footnotetext{
${ }^{9}$ For the unit root tests on cointegrating residuals, when unitary slope coefficient is imposed, we can reject the null at least at the 10 percent level. Given the low power of unit root tests in small samples, we consider these results quite favorable to long-run PPP.
} 
exchange rate is $\ln \left(\mathrm{E}_{\mathrm{i}, \mathrm{t}}\right)=-4.378+1.237^{*} \ln \left(\mathrm{R}_{\mathrm{i}, \mathrm{t}}\right)$. The coefficient on the log of the PPP exchange rate 1.237 is not significantly different from 1 ( with a standard error of 0.156$).^{10}$

\section{B. Short-Run Relationships}

\section{Error correction models}

If a cointegration relationship is established, then we can estimate an error-correction model which incorporates the long-run dynamics. In estimating short-run single equation relationships, we use the error correction specification in which lagged deviations from equilibrium are used as regressors. By estimating an error-correction model, we want to investigate the channels through which the nominal exchange rate adjusts in the short-run and to examine the predictability of short-run movements in nominal exchange rates.

Results for a generic variation of the single equation error correction models are reported in Table 3. The model is of the following form:

$$
\Delta\left(\ln \left(E_{i, t}\right)\right)=\alpha+\beta\left(\ln \left(E_{i, t-1}\right)-\gamma \ln \left(q_{i, t-1}\right)\right)+\sum_{j=1}^{j=k} \beta_{j} \Delta\left(\ln \left(E_{i, t-j}\right)\right)+\sum_{j=1}^{j=k} \delta_{j} \Delta\left(\ln \left(q_{i, t-j}\right)\right)
$$

where $\gamma$ is the normalized cointegrating coefficient or 1 (if imposing PPP).

Adjusted R-squares are reported for the models with different lags. For the export price indexes, it seems that the normalized error correction models perform better in terms of explanatory power than the models imposed PPP. And predictability improves when more lags of the nominal exchange rate and PPP exchange rate are added into the regression. The explanatory power of the error correction model tops at around 6 lags. This is also confirmed by the Akaike Information Criterion. The best- in terms of adjusted $\mathrm{R}^{2}$-models are reported in Table 3.

When the wholesale price indexes are used, the basic conclusion still holds. However, the difference between the normalized error correction model and the unitary sloped cointegrating model disappears. Recall that the normalized coefficient on the PPP exchange rate when wholesale prices are used is not significantly different from 1 , while the coefficient when export prices are used is significantly different from 1 , this may imply a fundamental difference in the use of these two different price indexes. Here, the predictive power of the error correction model tops at 5 lags. The best sets of models are also reported in table 3 .

\footnotetext{
${ }^{9}$ The same set of tests were also conducted on consumer price indexes. However, presumbaly because the CPI is a bad proxy for traded goods price, the results were very different from those for wholesale prices (WPI) and export prices (EPI). These results suggest that CPI should not be used to construct the relative price. Henceforth, we won't report the results on CPI.
} 
Basically, we see from this exercise that a substantial portion of the short-run movement in the nominal exchange rate can be explained by the error correction model (between 12 percent to 20 percent depending on the choice of the price indexes), which incorporates the equilibrium relationship between the nominal exchange rate and the PPP exchange rate. So, error correction models may prove a useful tool in predicting the short-run movement in nominal exchange rate.

The estimated error correction models imply different adjustment process depending on the number of lags used in the estimation. In the error correction models for the nominal exchange rate selected based on the highest adjusted $R^{2}$, the adjustment coefficient, the coefficient on the long-run cointegrating relationship, is not significant. As proved in Sims, Stock and Watson(1990), if a VAR is estimated with cointegrated nonstationary variables in levels, "the asymptotic distribution for the coefficients is identical to that for a model in which the cointegrating vector is known exactly a priori". We can choose the number of lags to include in an error correction model by choosing the lag length in a VAR estimated on the variables in their levels using the Schwartz Bayesian Criterion. In this case, the lag lengths are 3 and 2 for export price index and wholesale price index respectively. The models selected by the Schwartz criterion are reported in Table 4 with t-statistics in parenthesis. The adjustment process is significant for the nominal exchange rate.

\section{Autoregressive models}

The conventional wisdom of the finance literature states that movements in the nominal exchange rate are unpredictable. Changes in the nominal exchange rate should be uncorrelated over time.

In the literature on exchange rate forecasting, various monetary and PPP models have been proposed (Meese and Rogoff 1983). Yet, no one has looked at the usefulness of a simple autoregressive model of the nominal exchange rate. We found in our data that a simple AR(1) model can explain some of the variation in the change of the nominal exchange rate, the $\mathrm{AR}(1)$ coefficient is highly significant.

We present the following estimated $\mathrm{AR}(1)$ models for the nominal exchange rate. We also experimented with different AR orders. However, the AR(1) coefficients remain very stable across different order AR models and significant. A LM serial correlation test on the residual demonstrates that an $\mathrm{AR}(1)$ model is sufficient in accounting for the serial correlation in the change in the nominal exchange rate. The $\operatorname{AR}(1)$ and $\operatorname{AR}(4)$ are presented below: 


$$
\begin{gathered}
\Delta \ln \left(\mathrm{E}_{\mathrm{i}, \mathrm{t}}\right)= \\
-0.005+0.208^{*} \Delta \ln \left(\mathrm{E}_{\mathrm{i}, \mathrm{t}-\mathrm{l}}\right) \\
(-0.97)(1.99) \\
\Delta \ln \left(\mathrm{E}_{\mathrm{i}, \mathrm{t}}\right)=-0.005+0.209^{*} \Delta \ln \left(\mathrm{E}_{\mathrm{i}, \mathrm{t}-1}\right)-0.002 * \Delta \ln \left(\mathrm{E}_{\mathrm{i}, \mathrm{t}-\mathrm{2}}\right)-0.029 * \Delta \ln \left(\mathrm{E}_{\mathrm{i}, \mathrm{t}-3}\right)-0.063 * \Delta \ln \left(\mathrm{E}_{\mathrm{i}, \mathrm{t}-4}\right) \\
(-1.04)(1.94) \quad(-0.02) \quad(-0.26)
\end{gathered}
$$

The significant correlation in the change in nominal exchange rate could potentially result from data measurement. If the data for yen/dollar rate is taken from the Tokyo market, while that for the DM/dollar is taken from London market, then due to the time zone difference between the two markets, any news that hits the Tokyo market will have an effect on the London market the next period. Therefore, the exchange rate could appear serially correlated. However, since the data are quarterly, the impact of a one-day news lag is likely to be minimal.

Another possible source for autocorrelated changes in nominal exchange rates may be aggregation. If a data generating process is a continuous Wiener process, then aggregation over discrete sample periods will cause the resulting process to be autocorrelated with a MA(1) coefficient of 0.25 . Here, our data are the end of period market rates, which means no aggregation is done.

Therefore, this study is the first in finding a positively serially correlated change in nominal exchange rate.

\section{Short-run prediction of the exchange rate}

We have demonstrated that both our error correction models and an AR(1) model can explain some of the variation in the nominal exchange rate. However, it has been shown in the literature (Engel and Hamilton (1990), Diebold and Nason (1990)) that random walk forecast for the log of nominal exchange rates performs better than their model estimates. We want to compare our models with a standard random walk with drift model. We estimate the two error correction models selected by adjusted $\mathrm{R}^{2}$ and SIC, and a first-order autoregressive model on the changes of the nominal exchange rate from the first quarter of 1975 to the last quarter of 1992, then generate a three-year ahead dynamic forecast. Figure 2 graphs the various prediction against the actual nominal exchange rate, using the wholesale price index as the measure of prices.

The prediction labeled as ECM5 is generated by the model selected on highest adjusted $\mathrm{R}^{2}, \mathrm{ECM} 2$ is the one selected by SIC. Table 5 presents the prediction results and evaluation for the various models.

Both the error correction models and autoregressive model perform better than the random walk model, and the predictions from error correction models exceed or match the performance of the AR(1) model. This suggests that there is a systematic predictable component in the movement of the nominal exchange rate. The same exercise is repeated for 
the export price index (Table 6). Figure 3 graphs the various predictions against the actual nominal exchange rate for the export price index. The above conclusions basically remain the same.

We also followed Meese and Rogoff (1983) by dynamically estimating the model and forecasting at 1 to 4 quarter horizons ahead. The models are first estimated using data from the first quarter of 1975 to the last quarter of 1992, then a set of forecasts at 1 to 4 quarter horizons are calculated. The models are subsequently re-estimated with data from the first quarter of 1975 to the first quarter of 1993 , another set of forecasts generated. Every repetition adds one quarter of data at the end. The process repeats until all the data in the sample are used up. Then, three forecast evaluation criterion, root mean squared error, mean absolute error, and mean error, are calculated for all the forecasts. Forecast evaluations are reported in Tables 7 and 8 for wholesale price index and export price index, respectively.

Almost at all forecasting horizons, the two error correction models and the AR(1) model, outperform the random walk model, except for several cases where the error correction model is selected based on adjusted $\mathrm{R}^{2}$ slightly underperform the random walk model.

This constitutes, so far, the strongest evidence supporting predictability in the nominal exchange rate using exchange rate models based on PPP. ${ }^{11}$

\section{Directional accuracy measure of forecasting}

There are, however, strong criticisms against using only the conventional measures of forecasting accuracy based on a quadratic-loss function.(Cicarelli (1982), Tanner and Leitch (1991)). Such measures tend to pick out forecasts that are smooth over time, but miss out on turning point. However, the "missed turning points" are among the most serious errors a forecaster can make (Zarnowitz(1978)). Tanner and Leitch (1991) showed that the conventional criteria based on the size of forecasting error have no systematic bearing on profits. And, it was shown that the only forecast measure that correlates with profits is the "directional accuracy"(DA) proposed by Cicarelli (1982).

We decided to evaluate our different forecasts produced by the four models, AR(1), Random Walk, and the two error correction models, according to DA. Since there has been no attempt in the literature to formally test the significance of the difference in DA, we present a simple evaluation based on binomial probabilities.

"In MacDonald and Taylor (1992), they demonstrated that a monetary model of exchange rate determination can outperform the random walk forecast at all forecasting horizon for sterling-pound rate. 
In terms of direction, forecast changes consist of increases and decreases. When the forecast confirm the observed change, a correct prediction happens, otherwise a false prediction happens. As a result, we obtain the DA as a binomial variable taking the value of zero (or one), depending on whether a correct prediction happens (or not). The probability that a forecast model correctly predicts directional changes is given by the percentage of correct predictions out of all the forecasting predictions. Eventually, we would like to conduct a test on the difference between any two directional forecasting probabilities. However, at this stage, we reported the exact binomial probability of obtaining the number of success events given the prior success rate of 0.5 (random luck).

Results from this exercise are reported in Table 9. The AR(1) model on average gives the same probability of success as a random walk model, while the two error correction models generally give better predictions. The binomial probabilities are reported in parenthesis.

These results are among the first attempts to evaluate the predicting ability of exchange rate determination models based on a profit related measure. And they strongly suggest that the error correction models contain more useful information than the conventional random walk model.

\section{Long-Run Predictability of the Nominal Exchange Rate}

After evaluating the short-run movements in the nominal exchange rate, an assessment of its long-run behavior also seems interesting. If the short-run movement is somewhat predictable, then how far out can one predict the movement in the nominal exchange rate?

We decided to look at this question using a simple framework suggested by Hodrick (1992). Because the k-period change in the nominal exchange rate is the sum of $\mathrm{k}$ one-period changes, $\Delta\left(\ln \left(\mathrm{E}_{\mathrm{i}, \mathrm{t}+\mathrm{k}}\right)\right)=\Delta\left(\ln \left(\mathrm{E}_{\mathrm{i}, t+\mathrm{k}}\right)\right)+\ldots+\Delta\left(\ln \left(\mathrm{E}_{\mathrm{i}, \mathrm{t}+\mathrm{l}}\right)\right)$, then a regression of the following

$$
\Delta\left(\ln \left(\mathrm{E}_{\mathrm{i}, \mathrm{t}+\mathrm{k}}\right)\right)=\alpha_{\mathrm{k}}+\beta_{\mathrm{k}} \mathrm{X}_{\mathrm{t}}+\mathrm{u}_{\mathrm{t}+\mathrm{k}}
$$

where $X_{t}$ is the information set we have today to predict the future movement in exchange rate, measures the long-horizon predictability of $E_{i, t+k}$ by $X_{t}$. Direct estimation of equation (2) by OLS is infeasible because of the autocorrelated error terms. However, it can be proxied by the following model

$$
\Delta\left(\ln \left(\mathrm{E}_{\mathrm{t}+1}\right)\right)=\alpha+\beta\left(\mathrm{X}_{\mathrm{t}}+\mathrm{X}_{\mathrm{t}-1}+\ldots+\mathrm{X}_{\mathrm{t}-\mathrm{k}+1}\right)+\mathrm{u}_{\mathrm{t}+1}
$$


Because $\beta_{\mathrm{k}}$ in equation (2) is an estimate of $\operatorname{cov}\left[\Delta\left(\ln \left(\mathrm{E}_{\mathrm{i}, \mathrm{t}+\mathrm{k}}\right)\right)+\ldots+\Delta\left(\ln \left(\mathrm{E}_{\mathrm{i}, \mathrm{t}+\mathrm{l}}\right)\right) ; \mathrm{X}_{\mathrm{t}}\right]^{12}$, this covariance is equal to, when series are stationary, $\operatorname{cov}\left[\Delta\left(\ln \left(\mathrm{E}_{\mathrm{i}, \mathrm{t}+1}\right)\right) ; \mathrm{X}_{\mathrm{t}}+\mathrm{X}_{\mathrm{t}-1}+\ldots+\mathrm{X}_{\mathrm{t}-\mathrm{k}+1}\right]$. And if $\operatorname{var}\left(X_{t}\right)=\operatorname{var}\left(X_{t}+X_{t-1}+\ldots+X_{t-k+1}\right), \beta_{k}$ can be estimated by $\beta$. However, even if the two above variances are not equal, $\beta$ still provides a good proxy for the property of $\beta_{\mathrm{k}}$. Because if one is zero, then the other is zero as well. The explanatory power of equation (3) will give an estimate of the explanatory power of equation (2).

Here, our choice of $X_{t}$ is $\left(\ln \left(E_{i, t}\right)-\gamma \ln \left(q_{i, t}\right)\right)$, our cointegrating long-run equalibria, $\gamma$ can take the value of 1 or the normalized cointegrating coefficient.

The results for this exercise are presented in Table 10. As one can see that there is barely any long-horizon predictability in the movement of nominal exchange rate by the deviation from the long-run equilibria.

In the next section, we turn to the issue of investigating the long-run property of the real exchange rate.

\section{Long-Run Behavior of Real Exchange Rate}

The previous sections point out that there is a stable long-run relationship between the nominal exchange rate and relative price. This section will closely examine the long-run behavior of the real exchange rate implied if PPP holds.

The real exchange rate is defined as: $r_{t}=\ln \left(E_{i, t}\right)-\ln \left(R_{i, t}\right)$, where $E_{i, t}$ and $R_{i, t}$ are defined as in the section on purchasing power parity. If PPP holds continuously, then $r_{t}$ is a timeinvariant constant. However, due to substantial short-run deviations from PPP, the observed real exchange rate typically exhibit considerable short-term variability. Nonetheless, in the long haul, the real exchange rate should revert to its equilibrium value defined by PPP.

We have tested the stationarity of real exchange rate in section on cointegration tests and results when we discussed the cointegration issue. Here, we would adopt an approach based on real exchange rate autoregressions. Consider the following real exchange rate autoregression:

$$
r_{t}=\alpha_{0}+\alpha_{1} r_{t-1}+\mu_{1}
$$

12 Actually $\beta_{k}=\frac{\operatorname{cov}\left(\Delta\left(\ln \left(E_{i, t}\right)\right)+\Delta\left(\ln \left(E_{i, t+1}\right)\right)+\ldots+\Delta\left(\ln \left(E_{i, t+k}\right)\right), X_{t}\right)}{\operatorname{var}\left(X_{t}\right)}$ 
Long-run PPP depends critically on the estimate of the parameter $\alpha_{1}$. If $\left|\alpha_{1}\right| \geq 1$ longrun PPP does not hold. On the other hand, if $\left|\alpha_{1}\right|<1$, long-run PPP holds; and PPP is violated in the short-run whenever $r_{t}$ does not conform to its equilibrium value $r^{13}$. The speed of reverting to its fundamental value is $\left(1-\alpha_{1}\right)$ per period. Using the equilibrium value, equation (4) can be reformulated as

$$
\left(r_{t}-r^{\prime}\right)=\alpha_{1}\left(r_{t}-r^{\prime}\right)+\mu_{t}
$$

Equation (5) is used to make some inference about the speed of convergence to longrun PPP. The real exchange rate during our sample period $(75: 1-96: 2)$ displays a downward trend, which is in line with what has been discussed in Lothian(1990). So, we proxied the equilibrium value by a linear trend. Table 11 summarizes the results.

Both the export prices and wholesale prices provide support for long-run PPP. Point estimates of their autoregressive coefficients are below one. The 95 percent confidence interval safely excluded the unitary value. One can not use the standard t-test to test the hypothesis that $\alpha_{1}=1$, since its variance goes to infinity under the null. Dickey-Fuller's critical value is used in this case, and the null is strongly rejected at the 5 percent level. The point estimate of the autoregression coefficient implies that the speed of adjustment to longrun $\mathrm{PPP}$ is about 14 percent per quarter, and it takes about six quarters to reduce the deviation from equilibrium in half (half life). The point estimates also confirm the results in the unit root tests conducted on the real exchange rates in the section on unit root tests and results.

\section{ConCLUSIONS}

Although research testing long-run PPP has been proliferating in recent years, there are various topics deserving closer attention that have been addressed in the present work. In this research, I examine long-run PPP concerning a less researched bilateral exchange rate: the yen/DM rate. Without resorting to either panel data or long time horizon data on exchange rates, and using only quarterly data for the floating period, I am able to establish a series of interesting results.

The main result obtained in the paper is that the yen/DM rate exhibits long-run PPP when export prices or wholesale price indexes are used to construct the relative price, i.e., the PPP exchange rate in our definition. In addition, the conclusion is robust to different forms of test.

Using an error correction framework, I looked at the issue of predictability of the short-run and long-run movements in the nominal exchange rate. The results indicate that there is a substantial predictable component in the short-run movement of nominal exchange

\footnotetext{
${ }^{13}$ The equilibrium value of the real exchange rate can be written as: $\ddot{\mathrm{E}}=\mathrm{a}_{0} /\left(1-\mathrm{a}_{1}\right)$ by taking unconditional expectation in equation (8) after setting $r_{t-1}=r_{t}$.
} 
rate, and that the error correction models perform better in out-of-sample forecasting than the standard random walk model. This study is one of the first using "directional accuracy" measure of forecasting evaluation. It is found that the error correction models also perform better, according to DA. However, the long-horizon predictability of nominal exchange rates seems poor no matter what price indexes we use.

An autoregression approach was employed to examine the long-run behavior of the real exchange rate. The real exchange rate is shown to be mean-reverting in the long-run. And the point estimate of the autoregression coefficient demonstrates a converging speed of 14 percent per quarter, and a half-life of about six quarters.

The analysis was also partially carried out for the full sample period from the first quarter of 1957 to the last quarter of 1996, the basic results are not much affected except that the cointegration tests are less significant. This suggests that there may be a structural change undergone when switching from fixed exchange rate regime to flexible regime. And this may suggest that a time-varying parameter estimating framework be utilized to analyze a longer time period yen/mark rate. 


\section{REFERENCES}

Canzoneri, M.B., R.E. Cumby, and B. Diba, 1996, "Relative Labour Productivity and the Real Exchange Rate in the Long Run: Evidence for a Panel of OECD Countries," CEPR Discussion Paper, No.1464 (London: Centre for Economic Policy Research).

Cicarelli, J., 1982, "A New Method of Evaluating the Accuracy of Economic Forecasts," Journal of Macroeconomics, Vol. 4, No. 4 (Fall), pp.469-75.

Cumby, R.E., 1996, "Forecasting Exchange Rates and Relative Prices with the Hamburger Standard: Is What You Want What You Get with McParity?" NBER Working Paper No. 5675 (Cambridge, Massachusetts: National Bureau of Economic Research).

Dickey, D.A., and W.A. Fuller, 1981, "Likelihood Ratio Statistics for Autoregressive Time Series with a Unit Root," Econometrica, Vol. 49, pp.1057-72.

Diebold, F.X., and J. A. Nason, 1990, "Non-parametric Exchange Rate Prediction?" Journal of International Economics, Vol. 28 (3-4), pp.315-32.

Dornbusch, R., 1987, "Purchasing Power Parity," in The New Palgrave: A Dictionary of Economics, pp. 1075-85, ed. by John Eatwell, Murry Milgate and Peter Newman (Stockton, New York).

Engel, C., 1995, "Accounting for U.S. Real Exchange Rate Changes," Working Paper, University of Washington.

_ـ , 1996, "Long-Run PPP May Not Hold After All," NBER Working Paper No. 5646, (Cambridge, Massachusetts: National Bureau of Economic Research).

—, and J.D. Hamilton, 1990, "Long Swings in the Dollar: Are They in the Data and Do Markets Know it?" American Economic Review, Vol. 80(4), pp.689-713.

Engel, R.F., and C.W.J. Granger, 1987, "Co-integration and Error Correction: Representation, Estimation, and Testing," Econometrica, Vol. 55, pp.251-76.

Frankel, J.A., and R. Meese, 1987, "Are Exchange Rates Excessively Variable?" in NBER Macroeconomics Annual, pp. 117-53, ed. by Stanley Fischer (Cambridge, Massachusetts: MIT Press).

Froot, K., and K. Rogoff, 1995a, "The Law of One Price over 700 Years," NBER Working Paper No. 5132 (Cambridge, Massachusetts: National Bureau of Economic Research). 
and K. Rogoff, 1995b, "Perspectives on PPP and Long-Run Real Exchange Rates, in Hondbook of International Economics, ed. by Gene Grossman and Kenneth Rogoff, Vol. 3 (North Holland).

Fuller, W.A., 1976, "Introduction to Statistical Time Series," ed. by John Wiley (New York).

Hodrick, R.J., 1992, "Dividend Yields and Expected Stock Returns: Alternative Procedures for Inference and Measurement," Review of Financial Studies, Vol. 5(3), pp.357-86.

Jorion, P., and R. Sweeney, 1996, "Mean Reversion in Real Exchange Rates: Evidence and Implications for Forecasting," Journal of International Money and Finance, Vol. 5(4) (August), pp.535-50.

Lothian, J.R., 1990, "A Century Plus of Yen Exchange Rate Behavior," Japan and the World Economy, Vol. 2, pp.47-70.

-1995, "Capital Market Integration and Exchange Rate Regimes in Historical Perspective," Working Paper (Fordham University).

-1997, "Multi-Country Evidence on the Behavior of Purchasing Power Parity under the Current Float," Journal of International Money and Finance (February) Vol. $16(1)$, pp. 19-35.

_, and M. Taylor, 1996, "Real Exchange Rate Behavior: The Recent Float from the Perspective of the Past Two Centuries," Journal of Political Economy, Vol. 104(3), (June) pp. 488-509.

MacDonald, R., 1988, Floating Exchange Rates, Theories and Evidence, ed. by Unwin Hyman (London).

1993, "Long Run Purchasing Power Parity: Is It for Real?" Review of Economics and Statistics, Vol. 75, pp. 690-95.

and I.W. Marsh, 1994, "On Long- and Short-run Purchasing Power Parity," in Econometric Analysis of Financial Markets, ed. by Jurgen Kaehler and Peter Kugler, pp. 23-46.

and M.P. Taylor, 1991, "The Monetary Approach to the Exchange Rate: Long-Run Relationships and Coefficients Restrictions," Economics Letters, Vol. 37, pp. 179-85.

and M. Taylor, 1993, "The Monetary Approach to the Exchange Rate: Rational Expectations, Long-run Equilibrium, and Forecasting," Staff Papers, International Monetary Fund, Vol. 40 (January), pp. 89-107. 
and M. Taylor, 1994, "The Monetary Model of the Exchange Rate: Long-Run Relationships, Short-Run Dynamics and How to Beat a Random Walk, "Journal of International Money and Finance, Vol. 13(3), pp.276-90.

Mark, N.C., 1995, "Exchange Rates and Fundamentals: Evidence on Long-Horizon Predictability," American Economic Review (March), pp.201-16.

Meese, R., and K. Rogoff, 1983a, "Empirical Exchange Rate Models of the 1970s: Do They Fit Out of Sample?" Journal of International Economics (February), Vol. 14(1/2), pp.3-24.

and K. Rogoff, 1983b, "The Out of Sample Failure of Empirical Exchange Rate Models: Sampling Errors or Misspecification," in Exchange Rates and International Macroeconomics, ed. by Jacob Frenkel (Chicago, Illinois: University Press), pp.67105.

and K. Rogoff, 1988, "Was it Real? The Exchange Rate Interest Differential Relation Over the Modern Floating-Rate Period," Journal of Finance, Vol. 43(4), pp.933-48.

-1990, "Currency Fluctuations in the Post-Bretton Woods Period," Journal of Economic Perspective, (Winter), Vol. 4, pp. 117-34.

Parikh, A., 1991, "Modelling the Exchange Rate Behaviour of Yen and Deutsche Mark Against the Dollar," Weltwirstschaftliches-Archiv, Vol. 127(3), pp. 472-99.

1992, "An Econometric Study on the Yen-Pound Exchange Rate," International Review of Economics and Finance, Vol.. 1(3), pp.219-34.

Parsley, D.C., and S.J. Wei, 1995, "Convergence to Purchasing Power Parity without Trade Barriers or Currency Fluctuations," Working Paper (Harvard University: Kennedy School of Government).

Phillips, P.C.B., and P. Perron, 1988, "Testing for a Unit Root in Time Series Regression," Biometrika, Vol. 75 , pp. 335-46.

-and M. Loretan, 1991, "Estimating Long-run Economic Equilibria, Review of Economic Studies, Vol. 58, pp. 407-36.

Roll, R., 1979, "Violations of Purchasing Power Parity Puzzle," Journal of Economic Literature, Vol. 34, pp. 647-68.

Sims, C.A., J.H. Stock, and M.W. Watson, 1990, "Inference in Linear Time Series Models with Some Unit Roots," Econometrica, Vol. 58(1) (January), pp. 13-44. 
Tanner, J.E., and G. Leitch, 1991, "Economic Forecast Evaluation: Profits Versus the Conventional Error Measures," The American Economic Review, Vol. 81(3), (June) pp. 580-90.

Taylor, A.M., 1996, "International Capital Mobility in History: Purchasing Power Parity in the Long Run, NBER Working Paper No. 5742 (Cambridge, Massachusetts: National Bureau of Economic Research).

Tronzano, M., 1992, "Long-Run Purchasing Power Parity and Mean-Reversion in Real Exchange Rates: A Further Assessment," Economia Internazionale, Vol. 45(1), (February), pp. 77-100.

Wei, S.J. and D.C. Parsley, 1995, "Purchasing Power Disparity During the Floating Rate Period: Exchange Rate Volatility, Trade Barriers and Other Culprits," NBER Working Paper No. 5032 (Cambridge, Massachusetts: National Bureau of Economic Research).

Zarnowitz, V., 1978, "On the Accuracy and Properties of Recent Macroeconomic Forecasts," The American Economic Review, Vol. 68 (2), (May), pp. 313-19. 
Figure 1. Nominal Exchange Rates and Prices
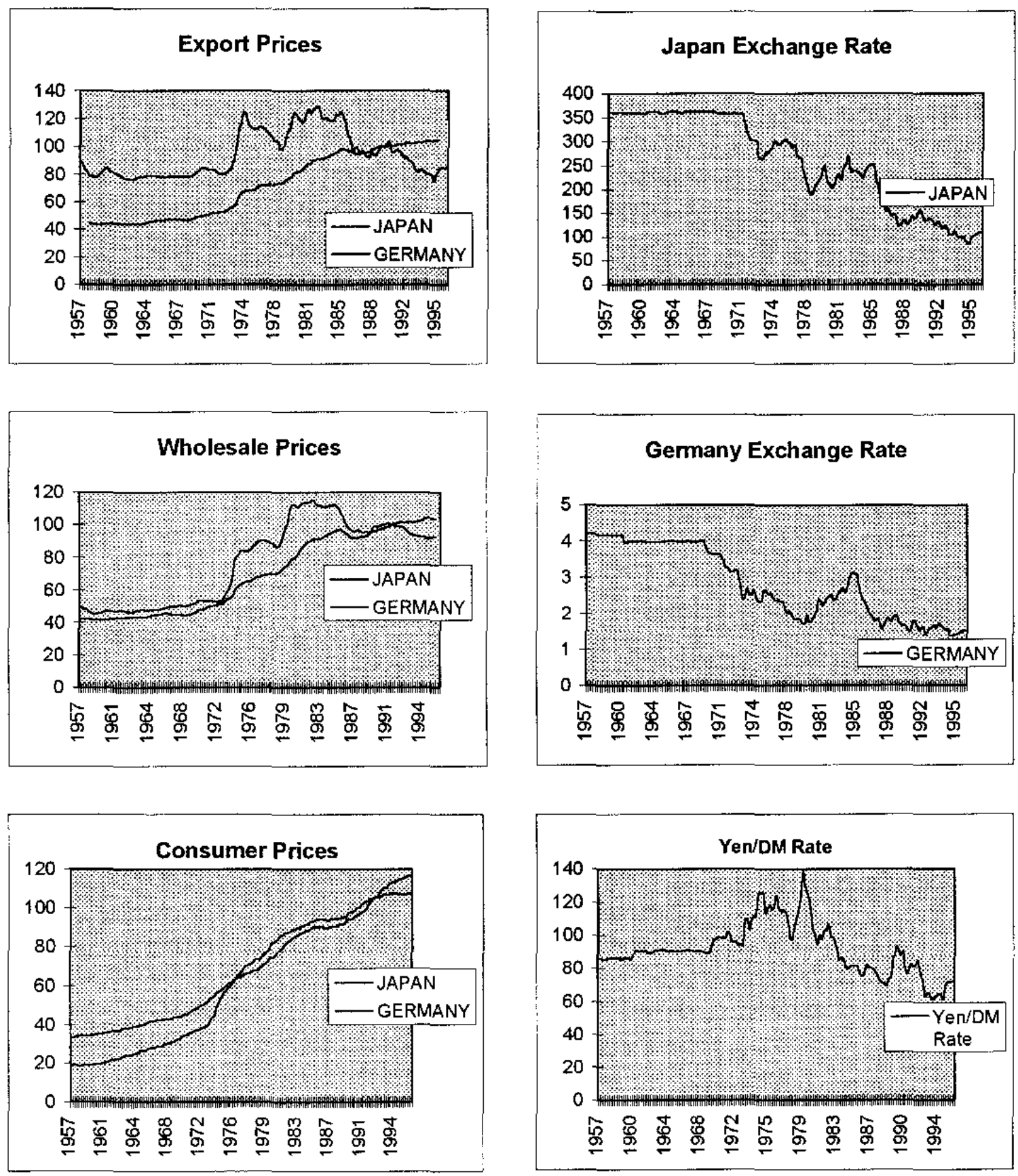
Figure 1. Nominal Exchange Rates and Prices (cont.)
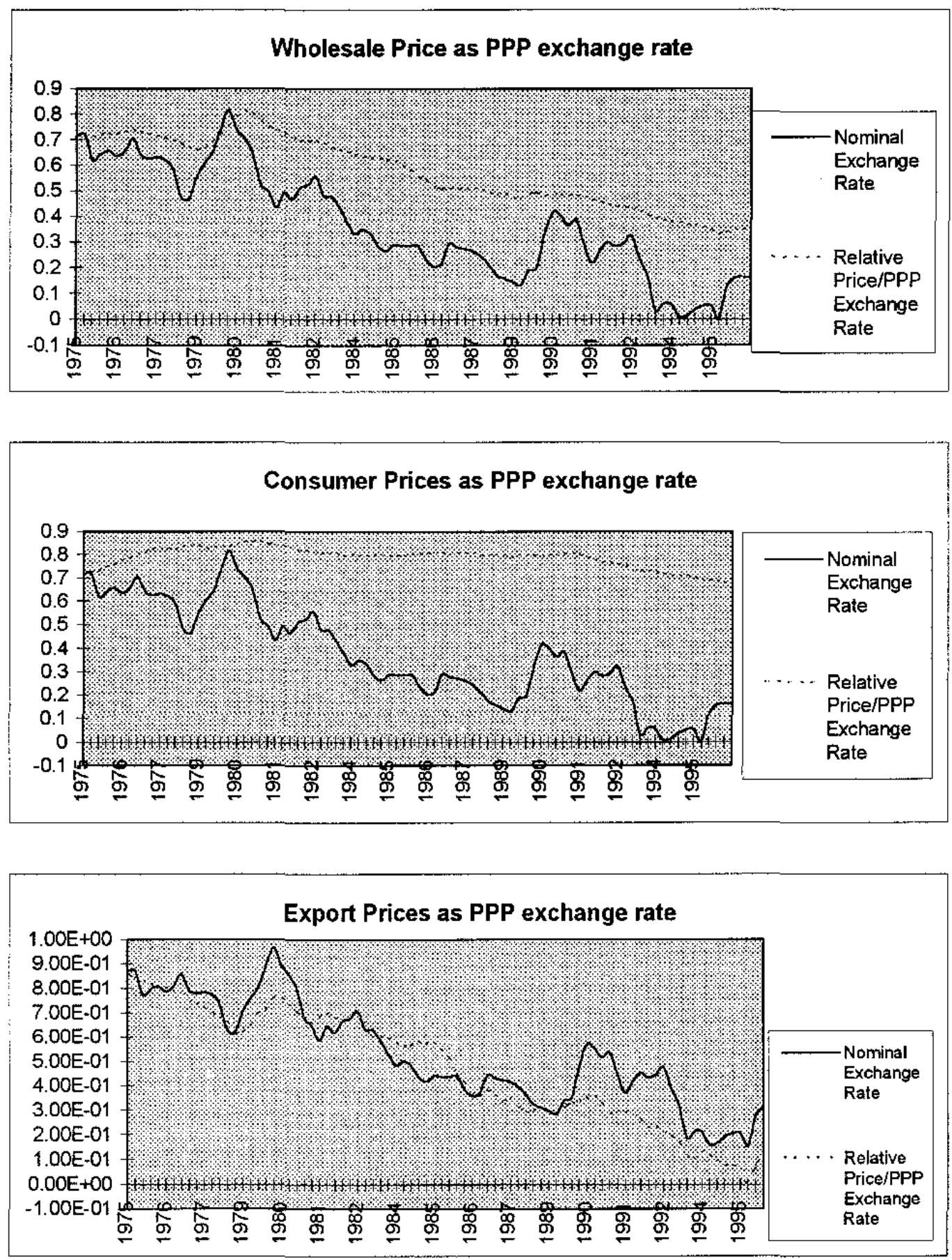
Figure 2. Prediction Based on Wholesale Price Index

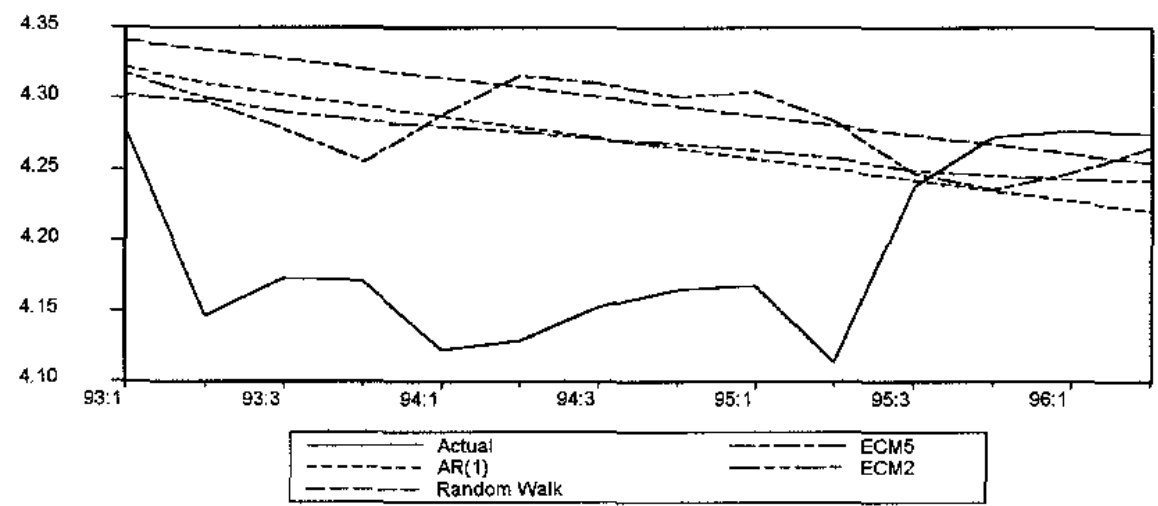

Figure 3. Prediction Based on Export Price Index

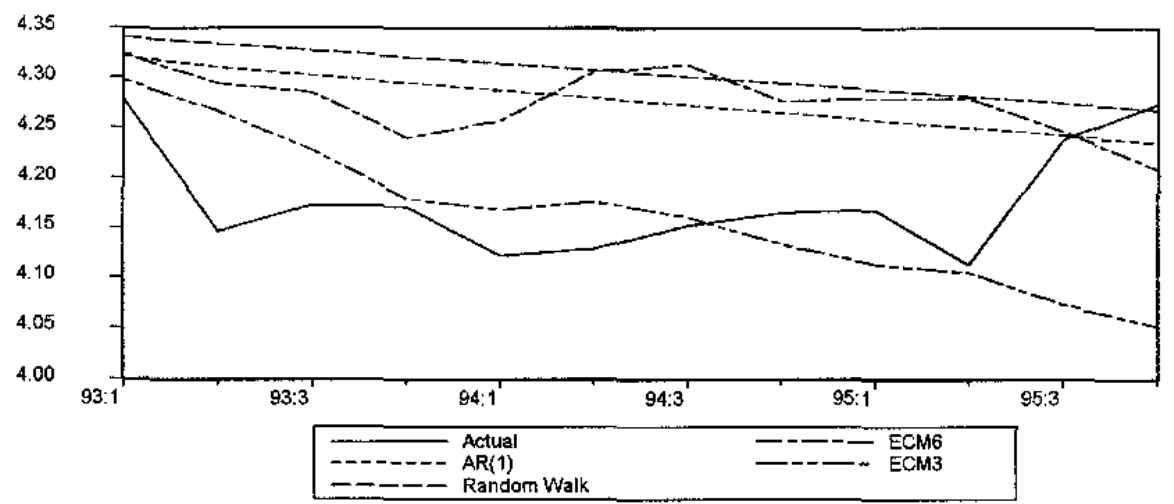


Table 1. Tests for Unit Roots

\begin{tabular}{|l|l|l|l|}
\hline Series & Yen/DM Rate & \multicolumn{1}{|c|}{$\begin{array}{c}\text { Relative Price } \\
\text { (Export prices) }\end{array}$} & $\begin{array}{c}\text { Relative Price } \\
\text { (Wholesale prices) }\end{array}$ \\
\hline $\mathrm{t}_{\rho}(\mathrm{ADF})$ with trend & -3.193 & -2.825 & -2.821 \\
\hline $\begin{array}{l}\mathrm{t}_{\rho}(\mathrm{ADF}) \text { without } \\
\text { trend }\end{array}$ & -1.743 & -1.129 & -0.448 \\
\hline lags & 1 & 1 & 1 \\
\hline $\begin{array}{l}\text { likelihood } \\
\text { ratio(ADF) }\end{array}$ & 5.216 & 1.392 & 4.087 \\
\hline $\mathrm{t}_{\rho}(\mathrm{PP})$ with trend & -3.172 & -2.778 & -2.449 \\
\hline $\mathrm{t}_{\rho}(\mathrm{PP})$ without trend & -1.644 & -1.061 & -0.241 \\
\hline likelihood ratio(PP) & 2.982 & 2.591 & 2.071 \\
\hline
\end{tabular}

Critical values for ADF:

(Without trend) $\quad 1 \% \quad-3.51$ (with trend) $1 \% \quad-4.04$

$$
\begin{array}{cccc}
5 \% & -2.89 & 5 \% & -3.45 \\
10 \% & -2.58 & 10 \% & -3.15
\end{array}
$$

Source: Fuller(1976) Table 8.5.2

Citical Values for Likelihood Ratio Tests: $1 \% \quad 8.73 \quad 5 \% \quad 6.49 \quad 10 \% 5.47$

Source: Dickey and Fuller(1981), p. 1063. 
Table 2. Cointegration Tests

\begin{tabular}{|l|l|l|}
\hline & Export Prices & Wholesale Prices \\
\hline $\begin{array}{l}\text { Johansen Cointegration } \\
\text { Test } \\
\text { Eigenvalue }\end{array}$ & 0.183 & \\
Likelihood Ratio & $22.974^{*}$ & 0.139 \\
\hline Residual Test & & $16.57^{\sharp}$ \\
\hline $\mathfrak{t}_{\rho}($ ADF $)$ without trend & -2.121 & Unitary Slope \\
\hline & & $-2.990^{\sim}$ \\
\hline$t_{\rho}($ PP) without trend & -2.431 & $-2.839^{\&}$ \\
\hline
\end{tabular}

$\&$ : reject unit root hypothesis at $10 \%$ only

$\sim$ reject unit root hypothesis at $5 \%$

*: reject no-cointegration at $5 \%$ level

\#: reject no-cointegration at $10 \%$ level. 
Table 3. Short-Run Predictability Using Error Correction Model

\begin{tabular}{|l|l|l|l|l|}
\hline & \multicolumn{2}{|c|}{ Export } & \multicolumn{1}{c|}{ Price } & \multicolumn{1}{c|}{ Wholesale } \\
\hline Adjusted $\mathrm{R}^{2}$ & Unitary Slope & $\begin{array}{l}\text { Cointegrating } \\
\text { Slope }\end{array}$ & $\begin{array}{l}\text { Unitary } \\
\text { Slope }\end{array}$ & $\begin{array}{l}\text { Cointegrating } \\
\text { Slope }\end{array}$ \\
\hline Lag = 1 & 0.04 & 0.08 & 0.06 & 0.06 \\
\hline Lag = 2 & 0.05 & 0.09 & 0.05 & 0.04 \\
\hline Lag =3 & 0.03 & 0.07 & 0.04 & 0.05 \\
\hline Lag =4 & 0.14 & 0.17 & 0.05 & 0.05 \\
\hline Lag =5 & 0.17 & 0.19 & 0.12 & 0.12 \\
\hline Lag =6 & 0.20 & 0.21 & 0.12 & 0.11 \\
\hline Lag =7 & 0.19 & 0.19 & 0.10 & 0.10 \\
\hline
\end{tabular}

Models based on the best adjusted $\mathrm{R}^{2}$ :

\section{Wholesale Price Index:}

Unitary Slope:

$$
\begin{aligned}
& \Delta\left(\operatorname{exr}_{t}\right)=0.30-0.07 *\left(\operatorname{exr}_{t-1}-\operatorname{relp}_{t-1}\right)+0.22 * \Delta\left(\operatorname{exr}_{t-1}\right)-0.01 * \Delta\left(\operatorname{exr}_{t-2}\right) \\
& (0.99)(-1.02) \\
& \text { (1.91) } \quad(-0.10) \\
& -0.01 * \Delta\left(\operatorname{exr}_{t-3}\right)+0.10 * \Delta\left(\operatorname{exr}_{t-4}\right)-0.3 * \Delta\left(\operatorname{exr}_{t-5}\right)+0.09 * \Delta\left(r e l p p_{t-1}\right) \\
& (-0.07) \quad(0.87) \quad(-2.75) \\
& +0.52 * \Delta\left(\operatorname{relp}_{t-2}\right)-0.33^{*} \Delta\left(\operatorname{relp}_{t-3}\right)-0.86^{*} \Delta\left(\mathrm{relp}_{t-4}\right)+0.43^{*} \Delta\left(\mathrm{relp} p_{t-5}\right) \\
& (0.77) \\
& (-0.53) \quad(-1.63)
\end{aligned}
$$




$$
\begin{aligned}
& \Delta\left(\operatorname{relp}_{t}\right)=-0.15+0.03 *\left(\operatorname{exr}_{t-1}-\operatorname{relp} p_{t-1}\right)+0.03 * \Delta\left(\operatorname{exr}_{t-1}\right)+0.01 * \Delta\left(\operatorname{exr}_{t-2}\right) \\
& (-2.52)(2.49) \quad(1.25) \quad(0.24) \\
& +0.01 * \Delta\left(\operatorname{exr}_{t-4}\right)-0.03 * \Delta\left(e x r_{t-5}\right)+0.42 * \Delta\left(r e l p_{t-1}\right)-0.04 * \Delta\left(r e l p p_{t-2}\right) \\
& (0.32) \quad(-1.50) \quad(3.59) \quad(-0.31) \\
& +0.06 * \Delta\left(\text { relp }_{t-3}\right)-0.05 * \Delta\left(\text { relp }_{t-4}\right)-0.18 * \Delta\left(\text { relp }_{t-5}\right) \\
& (0.47) \\
& (-0.49) \\
& (-2.12)
\end{aligned}
$$

Cointegrating Slope:

$$
\begin{aligned}
& \Delta\left(\operatorname{exr}_{t}\right)=0.34-0.08 *\left(\operatorname{exr}_{t-1}-1.24 * \operatorname{relp}_{t-1}\right)+0.23 * \Delta\left(\operatorname{exr}_{t-1}\right)-0.00 * \Delta\left(\operatorname{exr}_{t-2}\right) \\
& (0.92)(-0.95) \\
& (-0.00) \\
& -0.00 * \Delta\left(\operatorname{exr}_{t-3}\right)+0.11 * \Delta\left(\operatorname{exr}_{t-4}\right)-0.31 * \Delta\left(\operatorname{exr}_{t-5}\right)+0.07 * \Delta\left(\text { relp }_{t-1}\right) \\
& (-0.00) \\
& (0.90) \\
& (-2.65) \\
& +0.50 * \Delta\left(\operatorname{relp}_{t-2}\right)-0.35 * \Delta\left(\operatorname{relp}_{t-3}\right)-0.88 * \Delta\left(r e l p_{t-4}\right)+0.41 * \Delta\left(r e l p_{t-5}\right) \\
& (0.75) \\
& (-0.56) \\
& (-1.66) \\
& \Delta\left(\text { relp }_{t}\right)=-0.18+0.04 *\left(\operatorname{exr}_{t-1}-1.24 * \operatorname{relp}_{t-1}\right)+0.02 * \Delta\left(\operatorname{exr}_{t-1}\right)+0.00 * \Delta\left(\text { exr }_{t-2}\right) \\
& (-2.68)(2.64) \\
& +0.00 * \Delta\left(\operatorname{exr}_{t-4}\right)-0.04 * \Delta\left(e x r_{t-5}\right)+0.43 * \Delta\left(\text { relp }_{t-1}\right)-0.03 * \Delta\left(\text { relp }_{t-2}\right) \\
& (0.00) \\
& (-1.70) \\
& \text { (3.67) } \\
& (-0.23) \\
& +0.06 * \Delta\left(\text { relp }_{t-3}\right)-0.04 * \Delta\left(\text { relp }_{t-4}\right)-0.17 * \Delta\left(\text { relp }_{t, 5}\right) \\
& (-0.43) \\
& (-2.07)
\end{aligned}
$$

Export Price Index:

Unitary Slope:

$$
\begin{aligned}
& \Delta\left(\operatorname{exr}_{t}\right)=0.13-0.03 *\left(\operatorname{exr}_{t-1}-\operatorname{relp} p_{t-1}\right)+0.20 * \Delta\left(\operatorname{exr}_{t-1}\right)-0.02 * \Delta\left(\operatorname{exr}_{t-2}\right) \\
& (0.48)(-0.52) \\
& \text { (1.59) } \quad(-0.15) \\
& -0.04 * \Delta\left(\operatorname{exr}_{t-3}\right)+0.13^{*} \Delta\left(\operatorname{exr}_{t-4}\right)-0.23 * \Delta\left(\operatorname{exr}_{t-5}\right)-0.16^{*} \Delta\left(\operatorname{exr}_{t-6}\right) \\
& (-0.34) \\
& \text { (1.07) } \\
& (-2.01) \\
& (-1.32) \\
& -0.05 * \Delta\left(\operatorname{relp}_{t-1}\right)+0.19 * \Delta\left(\operatorname{relp}_{t-2}\right)+0.13 * \Delta\left(\operatorname{relp}_{t-3}\right)-0.76 * \Delta\left(\operatorname{relp}_{t-4}\right) \\
& (-0.20) \\
& \text { (0.78) } \\
& \text { (0.48) } \\
& (-3.05) \\
& +0.33 * \Delta\left(\text { relp }_{t-5}\right)-0.30 * \Delta\left(\text { relp }_{t-6}\right) \\
& (-1.26)
\end{aligned}
$$




$$
\begin{aligned}
& \Delta\left(\operatorname{relp}_{t}\right)=-0.21+0.05 *\left(\operatorname{exr}_{t-1}-r e l p_{t-1}\right)+0.10 * \Delta\left(\operatorname{exr}_{t-1}\right)-0.03 * \Delta\left(e x r_{t-2}\right) \\
& (-1.43)(1.36) \quad(1.51) \quad(-0.53) \\
& -0.06 * \Delta\left(\operatorname{exr}_{t-3}\right)-0.03 * \Delta\left(\operatorname{exr}_{t-4}\right)-0.01 * \Delta\left(\operatorname{exr}_{t-5}\right)+0.11 * \Delta\left(r e l p_{t-1}\right) \\
& \begin{array}{llll}
(-0.87) & (-0.52) \quad(-0.15) \quad(0.88)
\end{array} \\
& -0.12 * \Delta\left(\operatorname{relp}_{t-2}\right)+0.08 * \Delta\left(\operatorname{relp}_{t-3}\right)-0.06 * \Delta\left(\operatorname{relp}_{t-4}\right)-0.08 * \Delta\left(\operatorname{relp}_{t-5}\right) \\
& \left(\begin{array}{llll}
-0.91) & (0.61) \quad(-0.46) \quad(-0.58)
\end{array}\right. \\
& -0.11 * \Delta\left(\text { relp }_{t-6}\right) \\
& (-0.82)
\end{aligned}
$$

Cointegration Slope:

$$
\begin{aligned}
& \Delta\left(\operatorname{exr}_{t}\right)=0.33-0.08 *\left(\operatorname{exr}_{t-1}-0.8 * r e l p_{t-1}\right)+0.22 * \Delta\left(\operatorname{exr}_{t-1}\right)-0.00 * \Delta\left(\operatorname{exr}_{t-2}\right) \\
& \text { (0.90) }(-0.93) \quad(1.73) \quad(-0.00) \\
& -0.02 * \Delta\left(\operatorname{exr}_{t-3}\right)+0.14 * \Delta\left(\operatorname{exr}_{t-4}\right)-0.21 * \Delta\left(\operatorname{exr}_{t-5}\right)-0.14 * \Delta\left(\operatorname{exr}_{t-6}\right) \\
& (-0.20) \quad(1.20) \quad(-1.77) \quad(-1.14) \\
& -0.04 * \Delta\left(\operatorname{relp}_{t-1}\right)+0.20 * \Delta\left(\operatorname{relp}_{t-2}\right)+0.14 * \Delta\left(\operatorname{relp}_{t-3}\right)-0.76^{*} \Delta\left(\operatorname{relp}_{t-4}\right) \\
& (-0.16) \quad(0.82) \quad(0.53) \quad(-3.04) \\
& +0.32 * \Delta\left(\text { relp }_{t-5}\right)-0.30 * \Delta\left(\text { relp }_{t-6}\right) \\
& \text { (1.28) } \\
& (-1.25) \\
& \Delta\left(r e l p_{t}\right)=-0.30+0.07 *\left(e x r_{t-1}-0.80 * r e l p p_{t-1}\right)+0.09 * \Delta\left(e x r_{t-1}\right)-0.04 * \Delta\left(\operatorname{exr}_{t-2}\right) \\
& (-1.51)(1.46) \quad(1.34) \quad(-0.67) \\
& -0.06 * \Delta\left(\operatorname{exr}_{t-3}\right)-0.04 * \Delta\left(e x r_{t-4}\right)-0.02 * \Delta\left(\operatorname{exr}_{t-5}\right)-0.01 * \Delta\left(\operatorname{exr}_{t-6}\right) \\
& \begin{array}{llll}
(-0.95) & (-0.62) \quad(-0.30) & (-0.12)
\end{array} \\
& +0.11 * \Delta\left(\text { relp }_{t-1}\right)-0.13 * \Delta\left(\text { relp }_{t-2}\right)+0.08 * \Delta\left(\text { relp }_{t-3}\right)-0.07 * \Delta\left(\text { relp }_{t-4}\right) \\
& (0.83) \quad(-1.00) \quad(0.55) \quad(-0.52) \\
& -0.08 * \Delta\left(\text { relp }_{t-5}\right)-0.12 * \Delta\left(\text { relp }_{t-6}\right) \\
& (-0.59) \quad(-0.93)
\end{aligned}
$$


Table 4. Error Correction Models Selected Based on SIC

For the wholesale price index:

Unitary Slope:

$$
\begin{aligned}
\begin{aligned}
\Delta\left(\operatorname{exr}_{\mathrm{t}}\right)= & 0.55-0.13^{*}\left(\mathrm{exr}_{\mathrm{t}-1}-\mathrm{relp}_{\mathrm{t}-1}\right)+0.28^{*} \Delta\left(\mathrm{exr}_{\mathrm{t}-1}\right)+0.07 * \Delta\left(\mathrm{exr}_{\mathrm{t}-2}\right)+0.03 * \Delta\left(\mathrm{relp}_{\mathrm{t}-1}\right) \\
& (2.01)(-2.04) \\
- & 0.01 * \Delta\left(\mathrm{relp}_{\mathrm{t}-2}\right) \\
(-0.01) & (0.38) \\
\Delta\left(\text { relp }_{t}\right)= & -0.08+0.02 *\left(\operatorname{exr}_{t-1}-\operatorname{relp}_{t-1}\right)+0.04 * \Delta\left(\text { exr }_{t-1}\right)+0.01 * \Delta\left(\text { exr }_{t-2}\right) \\
& (-1.59)(1.55) \\
& +0.50 * \Delta\left(\text { relp }_{t-1}\right)-0.09 * \Delta\left(\text { relp }_{t-2}\right)
\end{aligned}
\end{aligned}
$$

Estimated Cointegrating Slope:

$$
\begin{aligned}
& \Delta\left(\operatorname{exr}_{t}\right)=0.55-0.3 *\left(\operatorname{exr}_{t-1}-1.24 * \operatorname{relp}_{\mathrm{t}-1}\right)+0.28 * \Delta\left(\operatorname{exr}_{t-1}\right)+0.07 * \Delta\left(\operatorname{exr}_{t-2}\right)+0.03 * \Delta\left(\operatorname{relp}_{t-1}\right) \\
& \text { (1.98) }(-2.00) \\
& -0.01 * \Delta\left(\text { relp }_{\mathrm{t}-2}\right) \\
& (-0.08) \\
& \Delta\left(\operatorname{relp}_{t}\right)=-0.11+0.02 *\left(\operatorname{exr}_{t-1}-1.24 * r e l p_{t-1}\right)+0.04 * \Delta\left(e x r_{t-1}\right)+0.01 * \Delta\left(\operatorname{exr}_{t-2}\right) \\
& (-1.86)(1.83) \\
& 0.49 * \Delta\left(\text { relp }_{t-1}\right)-0.09 * \Delta\left(\text { relp }_{t-2}\right) \\
& \text { (4.19) } \\
& (-0.81)
\end{aligned}
$$

\section{For the export price index:}

Unitary Slope:

$$
\begin{aligned}
& \Delta\left(\operatorname{exr}_{\mathrm{t}}\right)=0.36-0.08 *\left(\operatorname{exr}_{\mathrm{t}-\mathrm{l}}-\operatorname{relp}_{\mathrm{t}-1}\right)+0.23 * \Delta\left(\operatorname{exr}_{\mathrm{t}-1}\right)-0.04 * \Delta\left(\operatorname{exr}_{\mathrm{t}-2}\right)-0.06 * \Delta\left(\operatorname{exr}_{\mathrm{t}-3}\right) \\
& \text { (1.31) }(-1.31) \quad(1.85) \quad(-0.31) \quad(-0.49) \\
& +0.01 * \Delta\left(\operatorname{relp}_{\mathrm{t}-1}\right)+0.43 * \Delta\left(\operatorname{relp}_{\mathrm{t}-2}\right)+0.01 * \Delta\left(\operatorname{relp}_{\mathrm{t}-3}\right) \\
& (0.03)
\end{aligned}
$$




$$
\begin{aligned}
& \Delta\left(\operatorname{relp}_{t}\right)=-0.19+0.04 *\left(\operatorname{exr}_{t-1}-\operatorname{relp}_{t-1}\right)+0.11 * \Delta\left(\operatorname{exr}_{t-1}\right)-0.03 * \Delta\left(\operatorname{exr}_{t-2}\right) \\
& (-1.45)(1.38) \quad(1.91) \quad(-0.56) \\
& -0.08 * \Delta\left(e^{e x r_{t-3}}\right)+0.15 * \Delta\left(\operatorname{relp}_{t-1}\right)-0.10 * \Delta\left(\operatorname{relp}_{t-2}\right)+0.04 * \Delta\left(r e l p_{t-3}\right) \\
& (-1.36) \quad(1.22) \quad(-0.80) \quad(0.32)
\end{aligned}
$$

Estimated Cointegrating Slope:

$$
\begin{aligned}
& \Delta\left(\operatorname{exr}_{\mathrm{t}}\right)=0.77-0.17 *\left(\operatorname{exr}_{\mathrm{t}-1}-0.8 * \operatorname{relp}_{\mathrm{t}-1}\right)+0.26 * \Delta\left(\operatorname{exr}_{\mathrm{t}-1}\right)-0.00 * \Delta\left(\operatorname{exr}_{\mathrm{t}-2}\right)-0.01 * \Delta\left(\operatorname{exr}_{\mathrm{t}-3}\right) \\
& \text { (2.32) }(-2.33) \\
& \text { (2.13) } \\
& (0.00) \\
& +0.01 * \Delta\left(\operatorname{relp}_{\mathrm{t}-1}\right)+0.41 * \Delta\left(\operatorname{relp}_{\mathrm{t}-2}\right)+0.07 * \Delta\left(\operatorname{relp}_{\mathrm{t}-3}\right) \\
& (0.06) \\
& (0.25) \\
& \Delta\left(\operatorname{relp}_{t}\right)=-0.18+0.04 *\left(\operatorname{exr}_{t-1}-0.8 * \operatorname{relp}_{t-1}\right)+0.12 * \Delta\left(e x r_{t-1}\right)-0.03 * \Delta\left(\operatorname{exr}_{t-2}\right) \\
& (-1.11)(1.06) \\
& \text { (1.93) } \quad(-0.56) \\
& -0.08 * \Delta\left(e^{e x r_{t-3}}\right)+0.15 * \Delta\left(\text { relp }_{t-1}\right)-0.11 * \Delta\left(\text { relp }_{t-2}\right)+0.04 * \Delta\left(\operatorname{relp}_{t-3}\right) \\
& (-1.32)
\end{aligned}
$$


Table 5. Predictions of Exchange Rates (wholesale prices):

\begin{tabular}{|cccccc|}
\hline Year & Actual & $\mathrm{AR}(1)$ & Random Walk & ECM5 & ECM2 \\
\hline \multicolumn{5}{c}{} & \multicolumn{4}{c}{} \\
\hline $1993: 1$ & 4.277701 & 4.321972 & 4.340930 & 4.302644 & 4.317296 \\
\hline $1993: 2$ & 4.146827 & 4.310541 & 4.334265 & 4.297748 & 4.300149 \\
\hline $1993: 3$ & 4.173023 & 4.302232 & 4.327599 & 4.278135 & 4.290240 \\
\hline $1993: 4$ & 4.171178 & 4.294610 & 4.320933 & 4.255097 & 4.284185 \\
\hline $1994: 1$ & 4.122164 & 4.287140 & 4.314268 & 4.288639 & 4.280110 \\
\hline $1994: 2$ & 4.128500 & 4.279703 & 4.307602 & 4.316128 & 4.276108 \\
\hline $1994: 3$ & 4.152391 & 4.272273 & 4.300936 & 4.310069 & 4.271457 \\
\hline $1994: 4$ & 4.165086 & 4.264845 & 4.294271 & 4.300985 & 4.267945 \\
\hline $1995: 1$ & 4.167800 & 4.257417 & 4.287605 & 4.304266 & 4.263277 \\
\hline $1995: 2$ & 4.113173 & 4.249989 & 4.280939 & 4.284013 & 4.257855 \\
\hline $1995: 3$ & 4.238213 & 4.242562 & 4.274274 & 4.247668 & 4.249160 \\
\hline $1995: 4$ & 4.272958 & 4.235134 & 4.267608 & 4.235669 & 4.245463 \\
\hline $1996: 1$ & 4.276945 & 4.227706 & 4.260942 & 4.247275 & 4.242638 \\
\hline $1996: 2$ & 4.275234 & 4.220279 & 4.254277 & 4.265122 & 4.242085 \\
\hline $\begin{array}{l}\text { Root mean } \\
\text { squared error }\end{array}$ & 0.109785 & 0.130305 & 0.118927 & 0.105654 \\
\hline
\end{tabular}


Table 6. Predictions of Exchange Rates (export prices):

\begin{tabular}{|llllll|}
\hline Year & Actual & AR(1) & Random Walk & ECM5 & ECM2 \\
\hline & & & & \\
\hline $1993: 1$ & 4.277701 & 4.321972 & 4.340930 & 4.324105 & 4.297141 \\
\hline $1993: 2$ & 4.146827 & 4.310541 & 4.334265 & 4.294029 & 4.266075 \\
\hline $1993: 3$ & 4.173023 & 4.302232 & 4.327599 & 4.284947 & 4.227261 \\
\hline $1993: 4$ & 4.171178 & 4.294610 & 4.320933 & 4.240192 & 4.179363 \\
\hline $1994: 1$ & 4.122164 & 4.287140 & 4.314268 & 4.257233 & 4.168012 \\
\hline $1994: 2$ & 4.128500 & 4.279703 & 4.307602 & 4.305873 & 4.176465 \\
\hline $1994: 3$ & 4.152391 & 4.272273 & 4.300936 & 4.313150 & 4.160936 \\
\hline $1994: 4$ & 4.165086 & 4.264845 & 4.294271 & 4.276134 & 4.133103 \\
\hline $1995: 1$ & 4.167800 & 4.257417 & 4.287605 & 4.278961 & 4.113448 \\
\hline $1995: 2$ & 4.113173 & 4.249989 & 4.280939 & 4.278416 & 4.104206 \\
\hline $1995: 3$ & 4.238213 & 4.242562 & 4.274274 & 4.246379 & 4.072985 \\
\hline $1995: 4$ & 4.272958 & 4.235134 & 4.267608 & 4.208598 & 4.051352 \\
\hline $\begin{array}{l}\text { Root mean } \\
\text { squared error }\end{array}$ & 0.116653 & 0.140539 & 0.120021 & 0.092443 \\
\hline
\end{tabular}


Table 7. Rolling Forecasting Evaluation for Wholesale Price Index

\begin{tabular}{|c|c|c|c|c|c|c|}
\hline \multirow{2}{*}{ Model } & \multicolumn{3}{|c|}{ One Step Ahead } & \multicolumn{3}{c|}{ Two Step Ahead } \\
\hline & RMSE & MAE & ME & RMSE & MAE & ME \\
\hline AR(1) & 0.057 & 0.038 & -0.004 & 0.086 & 0.065 & -0.013 \\
\hline RW & 0.059 & 0.041 & -0.003 & 0.088 & 0.067 & -0.011 \\
\hline ECM5 & 0.061 & 0.039 & 0.004 & 0.090 & 0.069 & 0.010 \\
\hline ECM2 & 0.054 & 0.036 & 0.006 & 0.078 & 0.057 & 0.011 \\
\hline \multirow{2}{*}{ R Three Step Ahead } & & & & Four Step Ahead \\
\hline ECM2 & 0.076 & 0.059 & 0.008 & 0.082 & 0.070 & 0.008 \\
\hline AR(1) & 0.094 & 0.072 & -0.034 & 0.113 & 0.091 & -0.053 \\
\hline RW & 0.097 & 0.073 & -0.029 & 0.116 & 0.093 & -0.045 \\
\hline ECM5 & 0.095 & 0.073 & 0.006 & 0.115 & 0.099 & 0.006 \\
\hline
\end{tabular}


Table 8. Rolling Forecasting Evaluation for Export Price Index

\begin{tabular}{|c|c|c|c|c|c|c|}
\hline \multirow{2}{*}{ Model } & \multicolumn{3}{|c|}{ One Step Ahead } & \multicolumn{3}{c|}{ Two Step Ahead } \\
\hline & RMSE & MAE & ME & RMSE & MAE & ME \\
\hline AR(1) & 0.063 & 0.046 & 0.0002 & 0.098 & 0.079 & 0.005 \\
\hline RW & 0.064 & 0.049 & 0.002 & 0.098 & 0.077 & 0.010 \\
\hline ECM5 & 0.058 & 0.046 & 0.005 & 0.104 & 0.085 & 0.015 \\
\hline ECM2 & 0.063 & 0.049 & -0.012 & 0.097 & 0.073 & -0.021 \\
\hline & & Three Step Ahead & & Four Step Ahead \\
\hline RCM3 & 0.104 & 0.077 & -0.020 & 0.112 & 0.079 & -0.025 \\
\hline AR(1) & 0.116 & 0.087 & 0.018 & 0.136 & 0.104 & 0.023 \\
\hline RW & 0.118 & 0.085 & 0.023 & 0.139 & 0.106 & 0.029 \\
\hline ECM6 & 0.120 & 0.090 & 0.034 & 0.138 & 0.101 & 0.046 \\
\hline ECM & MAE & ME & RMSE & MAE & ME \\
\hline
\end{tabular}


Table 9. Directional Accuracy Measures of Forecasting

\begin{tabular}{|c|c|c|c|c|}
\hline DA & One Step & Two Step & Three Step & Four Step \\
\hline \multicolumn{5}{|c|}{ Wholesale Price Index } \\
\hline $\operatorname{AR}(1)$ & $\begin{array}{l}0.43 \\
(0.395)\end{array}$ & $\begin{array}{l}0.54 \\
(0.709)\end{array}$ & $\begin{array}{l}0.5 \\
(0.613)\end{array}$ & $\begin{array}{l}0.37 \\
(0.274)\end{array}$ \\
\hline RW & $\begin{array}{l}0.43 \\
(0.395)\end{array}$ & $\begin{array}{l}0.54 \\
(0.709)\end{array}$ & $\begin{array}{l}0.5 \\
(0.613)\end{array}$ & $\begin{array}{l}0.37 \\
(0.274)\end{array}$ \\
\hline ECM5 & $\begin{array}{l}0.57 \\
(0.788)\end{array}$ & $\begin{array}{l}0.54 \\
(0.709)\end{array}$ & $\begin{array}{l}0.67 \\
(0.927)\end{array}$ & $\begin{array}{l}0.64 \\
(0.887)\end{array}$ \\
\hline ECM2 & $\begin{array}{l}0.43 \\
(0.395)\end{array}$ & $\begin{array}{l}0.62 \\
(0.867)\end{array}$ & $\begin{array}{l}0.58 \\
(0.867)\end{array}$ & $\begin{array}{l}0.37 \\
(0.274)\end{array}$ \\
\hline \multicolumn{5}{|c|}{ Export Price Index } \\
\hline $\operatorname{AR}(1)$ & $\begin{array}{l}0.57 \\
(0.788)\end{array}$ & $\begin{array}{l}0.54 \\
(0.709)\end{array}$ & $\begin{array}{l}0.58 \\
(0.806)\end{array}$ & $\begin{array}{l}0.37 \\
(0.274)\end{array}$ \\
\hline RW & $\begin{array}{l}0.43 \\
(0.395)\end{array}$ & $\begin{array}{l}0.54 \\
(0.709)\end{array}$ & $\begin{array}{l}0.58 \\
(0.806)\end{array}$ & $\begin{array}{l}0.37 \\
(0.274)\end{array}$ \\
\hline ECM5 & $\begin{array}{l}0.57 \\
(0.788)\end{array}$ & $\begin{array}{l}0.46 \\
(0.500)\end{array}$ & $\begin{array}{l}0.67 \\
(0.927)\end{array}$ & $\begin{array}{l}0.55 \\
(0.726)\end{array}$ \\
\hline ECM2 & $\begin{array}{l}0.57 \\
(0.788)\end{array}$ & $\begin{array}{l}0.62 \\
(0.867)\end{array}$ & $\begin{array}{l}0.5 \\
(0.726)\end{array}$ & $\begin{array}{l}0.45 \\
(0.500)\end{array}$ \\
\hline
\end{tabular}

The probabilities in parenthesis are the exact binomial probabilities of obtaining the success event less or equal to the observed in the cell given prior success rate of 0.5 
Table 10. Long-Horizon Predictability Using OLS

\begin{tabular}{|c|l|l|l|l|}
\hline & \multicolumn{2}{c|}{ Export } & \multicolumn{1}{c|}{ Price } & \multicolumn{1}{c|}{ Wholesale } \\
\hline $\mathrm{R}^{2}$ & Unitary Slope & Cointegrating & Unitary Slope & Cointegrating \\
\hline $\mathrm{Lag}=1$ & 0.01 & 0.03 & 0.02 & 0.01 \\
\hline $\mathrm{Lag}=2$ & 0.03 & 0.06 & 0.04 & 0.03 \\
\hline $\mathrm{Lag}=3$ & 0.03 & 0.07 & 0.05 & 0.05 \\
\hline $\mathrm{Lag}=4$ & 0.03 & & 0.07 & 0.06 \\
\hline $\mathrm{Lag}=5$ & 0.03 & 0.07 & 0.07 & 0.08 \\
\hline $\mathrm{Lag}=6$ & 0.03 & 0.08 & 0.07 & 0.07 \\
\hline $\mathrm{Lag}=7$ & 0.01 & 0.07 & 0.05 & 0.05 \\
\hline
\end{tabular}

Table 11. Autoregressive Estimation for the Real Exchange Rate

\begin{tabular}{|c|c|c|}
\hline & Export Price & Wholesale Price \\
\hline$\alpha_{1}$ & 0.856 & 0.857 \\
\hline $95 \%$ Confidence & {$[0.849,0.862]$} & {$[0.851,0.864]$} \\
\hline Dickey-Fuller Test: & -2.51 & -2.52 \\
\hline
\end{tabular}

Critical Value for DF-test: $1 \%-3.51$

$$
\begin{array}{ll}
5 \% & -1.95 \\
10 \% & -1.61
\end{array}
$$

Source: Fuller(1976), table 8.5.2. 